\title{
Lokálisan és lokoregionálisan előrehaladott, magas kockázatú endometriumtumorok mütét előtti szisztémás előkezelése
}

\author{
Kalincsák Judit dr. ${ }^{1,2}$ - Gőcze Péter dr. ${ }^{1}$ - Bohonyi Noémi dr. ${ }^{1}$ \\ Bárdos Nikoletta dr. ${ }^{1}$. Koppán Miklós dr. ${ }^{1}$ - Kovács Krisztina dr. ${ }^{4}$ \\ Toller Gábor Lénárd dr. ${ }^{2}$ - Csima Melinda dr. ${ }^{3}$ - Papp Szilárd dr. ${ }^{1}$ \\ ${ }^{1}$ Pécsi Tudományegyetem, Általános Orvostudományi Kar, Klinikai Központ, \\ Szülészeti és Nőgyógyászati Klinika, Pécs \\ ${ }^{2}$ Somogy Megyei Kaposi Mór Oktató Kórház, Dr. Baka József Diagnosztikai, \\ Onkoradiológiai, Kutatási és Oktatási Központ, Kaposvár \\ ${ }^{3}$ Pécsi Tudományegyetem, Pedagógiai Kar, Pécs \\ ${ }^{4}$ Pécsi Tudományegyetem Általános Orvostudományi Kar, Klinikai Központ, Pathologiai Intézet, Pécs
}

\begin{abstract}
Bevezetés: A méhtestrák a fejlett országokban a leggyakoribb invazív nőgyógyászati daganat. A legjobb túlélési eredmények a tumor mútéti eltávolítása után várhatók, ezért a komplex ellátás célja a lokálisan és lokoregionálisan előrehaladott betegség reszekábilissé tétele.

Célkitüzés: A jelen közleményben azt vizsgáljuk, hogy a neoadjuváns kemoterápiával kezelt és mútéten átesett betegek teljes túlélése jobb-e a csak sugárkezelést kapott páciensekéhez képest.

Módszer: 2015. január és 2018. december között 28, lokálisan, illetve lokoregionálisan elörehaladott, primeren irreszekábilis, magas kockázatú méhtesttumoros betegnél végeztünk neoadjuváns szisztémás kezelést paklitaxel-karboplatin alkalmazásával. Ezt követően radikális hysterectomia, kétoldali petefészek-eltávolítás történt lymphadenectomiával.

Eredmények: A 6 ciklus kemoterápia után készült kontroll-MR-vizsgálat minden esetben méretbeli csökkenést igazolt. Minden betegnél véghez vihető volt a teljes tumoreltávolítás. A szövettani leletek alapján 4 páciens esetében igazolódott maradék tumor az eltávolított nyirokcsomókban. A 2 éves túlélési arány $65,5 \%$, a 2 éves progressziómentesség $66,1 \%$ volt. A medián teljes túlélés 16,5 hónap volt. Mindegyik érték jobbnak bizonyult a csak sugárkezelést kapó csoportnál.

Következtetés: A neoadjuváns kezelés hatékony módja lehet a reszekabilitás feltételeinek megteremtésében, ami túlélésbeli előnnyel járhat. A komplex ellátás ellenére a betegek túlélése továbbra is szerény.
\end{abstract}

Orv Hetil. 2020; 161(11): 425-433.

Kulcsszavak: lokálisan és lokoregionálisan előrehaladott endometriumcarcinoma, primeren irreszekábilis, neoadjuváns kezelés

Preoperative systemic treatment of locally and locoregionally advanced high-risk endometrial cancer

Introduction: Endometrial cancer is the most common invasive gynecologic malignancy in developed countries. The best survival rates are expected after surgical removal, thus the aim of a complex treatment is to achieve resecability in locally and locoregionally advanced disease.

Aim: The primary purpose of this study was to evaluate if the neoadjuvant systemic treatment leads to better overall survival compared to irradiation solely.

Method: From January 2015 to December 2018, we enrolled 28 patients diagnosed with irresecable, locally and locoregionally advanced high-risk endometrial carcinoma. Patients were treated by neoadjuvant paclitaxel-carboplatin, then radical hysterectomy, bilateral oophorectomy and lymphadenectomy were performed. 
Results: After administration of 6 cycles of carboplatin-paclitaxel, the control MR test showed tumor shrinkage in all patients. Complete resection was achieved in the case of every patient. Tumor residuum in lymph nodes was verified in 4 cases by pathological evaluation. The 2 -year survival and the 2 -year progression-free survival rates were $65,1 \%$ and $66,1 \%$, respectively. The median overall survival was 16,5 months.

Conclusion: Neoadjuvant treatment can be an effective approach in providing the conditions for complete tumor resection, which may result in survival advantage. Despite multimodal treatment, prognosis is poor.

Keywords: locally and locoregionally advanced endometrial carcinoma, primary irresecable, neoadjuvant treatment

Kalincsák J, Gőcze P, Bohonyi N, Bárdos N, Koppán M, Kovács K, Toller GL, Csima M, Papp Sz. [Preoperative systemic treatment of locally and locoregionally advanced high-risk endometrial cancer]. Orv Hetil. 2020; 161(11): $425-433$.

(Beérkezett: 2019. augusztus 12.; elfogadva: 2020. január 7.)

\section{Rövidítések}

AUC $=$ (area under the curve) görbe alatti terület; BMI = (body mass index) testtömegindex; BRCA $=$ (breast cancer antigen) emlőrákantigén; BSO = bilateralis salpingo-oophorectomia; $\mathrm{CAl} 25$ = (cancer antigen 125$)$ rákantigén-125; $\mathrm{CR}=$ (complete remission) komplett remisszió; DFS $=($ disease-free survival) betegségmentes túlélés; $\mathrm{EC}=$ endometriumcarcinoma; $\mathrm{EGFR}=$ (epidermal growth factor receptor $)$ az epidermális növekedési faktor receptora; ECOG = (Eastern Cooperative Oncology Group) Keleti Onkológiai Társasági Együttmúködés; ESGO = (European Society of Gynaecological Oncology $)$ Európai Nőgyógyász Onkológusok Társasága; ESMO = $(\mathrm{Eu}-$ ropean Society for Medical Oncology) Európai Klinikai Onkológiai Társaság; ESTRO = (European Society for Radiotherapy and Oncology) Európai Sugárterápiás és Onkológiai Társaság; FIGO = (Fédération Internationale de Gynécologie et d'Obstétrique) Nemzetközi Szülészeti és Nőgyógyászati Szövetség; FDG = fluoro-dezoxi-glükóz; $\mathrm{GOG}=($ Gynecologic Oncology Group) Nőgyógyászati Onkológiai Munkacsoport (Amerikai Egyesült Államok); KRAS = (Kirsten rat sarcoma viral oncogene) a Kirsten-patkány-sarcoma virális onkogénje; MAPK $=($ mitogen-activated protein kinase $)$ mitogén aktiválta proteinkináz; MMMT = (malignant mixed Müllerian tumor $)$ malignus kevert Müller-cső-eredetű daganat; $\mathrm{mTOR}=(\mathrm{mam}-$ malian target of rapamycin) emlős rapamycin-célpont; $\mathrm{MR}=$ (magnetic resonance) mágneses rezonancia; $\mathrm{NCCN}=($ National Comprehensive Cancer Network) Nemzeti Átfogó Onkológiai Hálózat (Amerikai Egyesült Államok); OS = (overall survival) teljes túlélés; PDLl $=($ programmed death-ligand 1$)$ programozott halál ligand-1; PFS $=$ (progression-free survival $)$ progressziómentes túlélés; PI3K = (phosphatidylinositol 3-kinase) foszfatidilinozitol-3-kináz; $\mathrm{PR}=$ parciális regresszió; PTE KK = Pécsi Tudományegyetem, Klinikai Központ; PTEN = (phosphatase and tensin homolog) foszfatáz- és tenzinhomológ; RECIST $=$ (response evaluation criteria in solid tumors) szolid tumorok radiológiai válaszát értékelő kritériumok; $\mathrm{SD}=($ stable disease $)$ stabil állapot; $\mathrm{TAH}=$ totális abdominalis hysterectomia; TKI = tirozin-kináz-inhibitor

A méhtestrák a fejlett országokban a leggyakoribb invazív nőgyógyászati daganat, az újonnan felfedezett nőgyógyászati daganatok 50\%-a; világszerte 320000 az új eset. Az 5 éves túlélés csak szerény mértékben javult Európában az utóbbi évtizedekben, Nyugat-Európában jelenleg ez körülbelül átlag 60\% az összesített túlélésre vonatkozóan. Az 5 éves túlélési esély különböző a szövettani szubtípusok szerint: adenocarcinoma esetén $83 \%$, világos sejtes carcinoma esetén $62 \%$, serosus papillaris tumor esetén $53 \%[1,2]$.

Kialakulásuk szempontjából a tumorok malignus hámés malignus mesenchymalis eredetúek lehetnek. A hámeredetúek között két altípust különböztetünk meg: az I-es típusba kedvező prognózisú, rendszerint jól vagy közepesen differenciált, tiszta endometrioid komponensű, menopausa körüli időszakban kifejlődő, ösztrogénhatástól függő tumorok tartoznak, melyek az endometriumcarcinomák (EC-k) 85\%-át teszik ki, míg a II-es típusúak általában idősebb korban, atrophiás endometriumban kialakuló, hormonexpozícióval nem összefüggő, kevésbé differenciált daganatok rosszabb prognózissal. Ebbe a csoportba soroljuk a serosus, világos sejtes, dedifferenciált EC-t és a malignus kevert Müller-cső-eredetú tumort vagy carcinosarcomát. A malignus mesenchymalis eredetú tumorok közé a méhtestsarcomák tartoznak: 'low-grade' és 'high-grade' endometrialis stromalis sarcoma, dedifferenciált uterussarcoma, valamint az uterusleiomyosarcoma. A kockázati tényezők közül kiemelendő a menstruációs időszak intervalluma (korai menarche, késői menopausa), a nulliparitás, az exogén vagy endogén ösztrogénstimulus, az obesitas, kísérő betegségként a diabetes, a hypertonia, a polycystás ovarium. Az elhízás, a 30 feletti BMI 3-4-szeres rizikóemelkedést jelent. Ezenfelül Lynch-szindróma esetén 30-60\%-kal nagyobb az EC kialakulásának kockázata. A molekuláris genetikai tényezők közül a BRCAl, PTEN, p53 és mis-match repair gének hibáit írták le örökletes tényezóként. Az I-es típusú EC esetén a PI3K jelátviteli út zavara áll fenn nagyrészt, valamint PIK3CA, KRAS protoonkogén, FDFR2 mutáns gének azonosíthatók. A leggyakoribb mégis a PTEN (50\%) és KRAS (25\%) protoonkogének eltérése. A magas gradusú, rossz prognosztikájú II-es tí- 
pusba tartozó EC esetén p53-mutáció és ERBB2-amplifikáció észlelhetô [3].

A prognosztikai tényezőket figyelembe véve különböző kockázati csoportokba sorolhatók a betegek, amelyek alapján következtetni lehet a betegségmentes és teljes túlélésre is.

\section{Az endometriumtumorok szisztémás kezelése}

Endometriumtumorok esetén a leghatékonyabb cytostaticumnak a platinatartalmú, taxánt tartalmazó kombinációk tünnek. Az ESMO-ajánlás alapján is hatékonyabbak, valamint kevésbé toxikusak a ciszplatin-doxorubicin-paklitaxel kombinációhoz képest. A paklitaxel kombinálása karboplatinnal tûnik a leghatékonyabbnak a több mint 60\%-os válaszrátával, valamint hosszabb túléléssel, összehasonlítva az egyéb, paklitaxelt nem tartalmazó kombinációkkal. Lokálisan előrehaladott stádiumban, az első vonalban és recidív betegség esetén ezt a kombinációt javasolják EC esetén. A GOG 2009. évi, fázis 3-as 'non-inferiority' vizsgálata karboplatin-paklitaxel és ciszplatin-doxorubicin-paklitaxel alkalmazását hasonlította össze III-IV. stádiumú vagy rekurráló EC esetén. Azonos teljes és progressziómentes túlélés mellett jelentősen csökkent Grade 2 és annál magasabb fokozatú toxicitást észleltek. Karboplatin-paklitaxelre 50\% vagy magasabb válaszrátát találtak mind az adjuváns, mind a neoadjuváns csoportban.

A több célpontú, antitumoralis és antiangiogenetikus PI3K, mTOR jelátviteli utak gátlását célzó terápiák hozhatnak jobb eredményt a közeljövőben az EC-k tekintetében. PDLl-pozitív endometriumdaganatokban a pembrolizumab-monoterápia szerepét a KEYNOTE-028 klinikai vizsgálatban mérték fel: az eredmények alapján tartós antitumor-aktivitással rendelkezik [4]. Második vonalbeli kezelésre vonatkozóan továbbra sincs egyértelmü ajánlás, a válaszráta meglehetősen alacsony. A paklitaxel, oxaliplatin, topotekán, liposzomális doxorubicin, etopozid, ciklofoszfamid, pemetrexed, gemcitabin hatékonyságát tesztelve a paklitaxel tünt a leghatékonyabbnak, de a válaszráta alig éri el a 20\%-ot [5-11]. Trabektedin adásával kapcsolatban is történt vizsgálat előzetesen onkológiai kezelésben részesített EC-k esetén, minimális tumorellenes hatást tapasztaltak [12]. Jelenleg méhtestleiomyosarcoma esetén ajánlják alkalmazását.

\section{Célkitüzés}

A nőgyógyászati tumorok közül a petefészek-daganatok esetében széles körben alkalmaznak szisztémás előkezelést követően intervallum-laparotomiát, mely teljes tumoreltávolítást tesz lehetővé csökkent műtéti radikalitás mellett, csakúgy, mint az onkológia egyéb szolid tumorainál, úgymint lokálisan és lokoregionálisan előrehaladott emlő- vagy tüdődaganatok esetén. A lokálisan, illet- ve lokoregionálisan előrehaladott endometriumtumorok ellátására vonatkozóan a nemzetközi ajánlások neoadjuváns kemoterápia alkalmazása utáni mütéti eltávolítást, illetve sugárkezelés adását javasolják. A neoadjuváns kemoterápiára vonatkozóan kevés irodalmi adat van. A vizsgálat célja a neoadjuváns kemoterápia és az azt követő mútét, vagy sugárterápia adása után észlelt túlélési adatok összehasonlítása egymással, illetve a szakirodalmi eredményekkel.

\section{Betegek és módszer}

A PTE KK Szülészeti és Nőgyógyászati Klinikájának Onkológiai Osztályán 2015. január és 2018. december között 28, lokálisan előrehaladott, primeren irreszekábilis, magas kockázatú méhtesttumoros betegnél alkalmaztunk neoadjuváns szisztémás kezelést onkoteam döntése alapján. Minden esetben a küret szövettani eredménye erősítette meg a malignitást. Bármelyik EC-szubtípus beválasztható volt, a sarcomát azonban kizáró tényezőként határoztuk meg. A betegbeválasztás során jó általános állapotú (ECOG: 0-1), megfelelő kardiális állapotú betegeket választottunk ki; feltétel volt az esetleges későbbi mütéthez az operabilitás.

A pontos stádium meghatározására mellkasröntgen és has-kismedence MR-vizsgálat készült, valamint a CAl25 tumormarker meghatározása történt. A beválasztott pácienseknél III/A-IV/A stádiumú endometriumtumor igazolódott.

Minden esetben paklitaxel-karboplatin kezelést végeztünk. A paklitaxelt $175 \mathrm{mg} / \mathrm{m}^{2}$ dózisban adtuk, a karboplatint AUC 5 szerint számolva. 4 ciklus kemoterápia megadása után kontroll-MR-vizsgálat készült a terápia hatékonyságának felmérésére. A terápiás választ RECIST

\begin{tabular}{l|l} 
1. táblázat & $\begin{array}{l}\text { A neoadjuváns kezelésben, majd mútétben részesített, illetve } \\
\text { elsődlegesen sugárkezelt betegcsoport fó jellemzőinek összeha- } \\
\text { sonlítása }\end{array}$
\end{tabular}

\begin{tabular}{lcc}
\hline Jellemző tulajdonságok & $\begin{array}{c}\text { Neoadjuváns } \\
\text { kezelésben, } \\
\text { majd mútétben } \\
\text { részesített } \\
\text { betegcsoport } \\
\mathrm{n}=28\end{array}$ & $\begin{array}{c}\text { Sugárkezelt } \\
\text { betegcsoport } \\
\mathrm{n}=27\end{array}$ \\
\hline Átlagéletkor & 62,4 év & 63,1 év \\
\hline Átlag-BMI & 34,6 & 34,1 \\
\hline Átlaggraviditás & 1,9 & 2,1 \\
\hline Átlagparitás & 1,7 & 1,9 \\
\hline Az elözményekben hypertonia & 17 & 20 \\
\hline Az elözményekben diabetes & 10 & 13 \\
\hline $\begin{array}{l}\text { A diagnóziskor észlelt } \\
\text { szövettan: } \\
\text { - adenocarcinoma }\end{array}$ & 19 & 22 \\
\hline $\begin{array}{l}\text { - serosus papillaris carcinoma } \\
\text { - világos sejtes carcinoma }\end{array}$ & 5 & 3 \\
\hline
\end{tabular}

$\mathrm{BMI}=$ testtömegindex 
1.1 szerint értékeltük. Parciális regresszió, stabil betegség esetén a kezelést folytattuk további 2 ciklus megadásával, majd ismételt MR-kontrollt követően mútét történt. Non-responder betegek esetén definitív sugárkezelést terveztünk.

Eredményeinket a klinikánkon osztályos elhelyezésben részesített, hasonló stádiumú és betegszámú $(\mathrm{n}=27)$, sugárkezeléssel ellátott, mütétben nem részesített populációval hasonlítottuk össze a szövettani sajátosságok, tumorkiterjedés, életkor, társbetegségek tekintetében (1. táblázat).

A túlélési eredmények számításához Kaplan-Meieranalízist, Cox-regressziót, kétmintás t-próbát és log-rank tesztet használtunk fel.

\section{Eredmények}

Szisztémás előkezelést 28 beteg kapott. A betegek átlagéletkora 62,4 év (41-88), az átlag-BMI 34,6 (29,1$40,1)$ volt. Normál testsúlyú beteg nem volt. A betegek 50\%-a a II. típusú elhízás csoportjába tartozik, III. fokú elhízást 14\%-ban találtunk. Graviditásátlag: 1,9 (0-4), paritásátlag: 1,7 (0-3). Az anamnézisben 17 esetben volt felfedezhető hypertonia $(60,7 \%), 10$ esetben diabetes mellitus $(35,7 \%)$. Két esetben korábbi emlőtumor komplex ellátásán belül tamoxifenkezelés szerepelt az előzményekben. A preoperatív küret során 19 adenocarcinoma, 5 serosus papillaris carcinoma és 4 világos sejtes carcinoma igazolódott. 64,2\%-ban magas gradusú, 35,8\%-ban alacsony gradusú specimen igazolódott. A klinikai stádium megoszlása az alábbi volt: 2 esetben III/A $(7,1 \%), 3$ esetben III/B (10,7\%), 4 esetben III/Cl (14,2\%), 9 esetben III/C2 (32,2\%), 10 esetben pedig IV/A stádium $(35,8 \%) .22$ beteg $(78,6 \%)$ esetén volt nyirokcsomóérintettség a kiindulási képalkotó során, valamint 18 esetben $(64,3 \%)$ észleltünk emelkedett CA125-értéket. A kemoterápia prolongálására nem volt szükség, megfelelő szupportáció alkalmazása mellett véghez vihető volt, dózisredukcióra nem került sor. A 6 ciklus kemoterápia után készült kontroll-MR-vizsgálat minden esetben méretbeli csökkenést igazolt: 3 esetben $20 \%$ alatti választ $(10,71 \%)$ - SD, 6 esetben teljes regressziót igazolt $(21,42 \%)$ - CR, 19 esetben $(67,85 \%) 30 \%$-ot meghaladó parciális regressziót - PR. Az operáció során minden esetben TAH és BSO történt lymphadenectomiával. A mütétek elvégzésében 6 nőgyógyász vett részt. Az eltávolított nyirokcsomók száma átlag 18 volt (1-37). Az eltávolítás minden esetben teljes volt. A preoperatív szövettan 2 esetben változott a mútét utáni specimen patológiai feldolgozása során adenocarcinomáról carcinosarcomára. A posztoperatív szövettan 1 esetben igazolt II-es gradusú folyamatot, a többi specimenben magas gradusú folyamat igazolódott a részletes feldolgozás során. A mútét előtti képalkotó vizsgálathoz képest további 2 esetben parciális regresszió látszott. A posztoperatív T-stádium eredményei alapján leírható, hogy sokkal alacsonyabb volt az előrehaladottabb stádiumú daganatok
2. táblázat $\mid$ A neoadjuváns kemoterápiával kezelt páciensek mútét előtti képalkotó vizsgálatokkal megállapított staging vizsgálati eredményeinek és a mútéti preparátum feldolgozásával kapott patológiai staging vizsgálatok eredményeinek összehasonlítása

\begin{tabular}{lcc}
\hline T-stádium & $\begin{array}{c}\text { A preoperatív staging } \\
\text { alapján megállapított } \\
\text { T-stádium száma }\end{array}$ & $\begin{array}{c}\text { A mútéti preparátum } \\
\text { patológiai vizsgálata alapján } \\
\text { megállapított yT-stádium } \\
\text { száma }\end{array}$ \\
\hline 0 & 0 & 2 \\
l/a & 0 & 5 \\
$1 / \mathrm{b}$ & 0 & 10 \\
2 & 0 & 9 \\
$3 / \mathrm{a}$ & 8 & 1 \\
$3 / \mathrm{b}$ & 10 & 0 \\
$4 / \mathrm{a}$ & 10 & 0 \\
\hline
\end{tabular}

aránya: yT0-yTl-es stádium 17 páciens esetében, szemben a mütét előtti T-stádium eredményeivel, amelynél a cT3-4-es stádium volt domináns. A neoadjuváns kezelés előtt 19 betegnél detektált a képalkotó vizsgálat nyirokcsomóáttétet, előkezelés után pedig csak 4 esetben, ami megegyezett a patológiai feldolgozás során igazolt nyirokcsomó-érintettséggel (2. táblázat).

$\mathrm{Az}$ adjuváns kezelés kemoterápiát és/vagy sugárkezelést foglalt magában. Adjuváns kezelés 12 esetben történt, az esetek $42,85 \%$-ában. 8 esetben hüvelyi közelterápia, 4 esetben kombinált külső kismedencei és belső sugárkezelés.

Eredményeinket a klinikánkon osztályos elhelyezésben részesített, hasonló stádiumú és betegszámú ( $\mathrm{n}$ = 27), sugárkezeléssel ellátott, mütétben nem részesített populációval hasonlítottuk össze a szövettani sajátosságok, tumorkiterjedés, életkor, társbetegségek tekintetében. A betegek átlagéletkora 63,1 év (43-83), az átlagBMI 34,1 (21,2-42,3) volt. 2 beteg kivételével az összes páciens túlsúlyos vagy elhízott volt. A graviditásátlag 2,1 (0-3), a paritásátlag 1,9 (0-4) volt. A kórelőzményben 20 esetben szerepelt hypertonia $(74 \%), 13$ esetben diabetes mellitus $(48,1 \%) .4$ esetben korábbi emlótumor miatt tamoxifenkezelés szerepelt. A preoperatív küret alapján 22 adenocarcinoma, 3 serosus papillaris carcinoma és 2 világos sejtes carcinoma igazolódott. A klinikai stádium megoszlása az alábbiak szerint oszlott meg: 1 esetben III/A (3,7\%), 2 esetben III/B (7,4\%), 7 esetben III/C1 $(25,9 \%), 8$ esetben III/C2 (29,6\%), 9 esetben pedig IV/A stádium $(33,4 \%) .24$ beteg $(88,9 \%)$ esetén találtunk nyirokcsomó-érintettséget a kiindulási képalkotó során. A betegek felénél normáltartományon felüli CA125-értéket észleltünk. A sugárkezelés során 50 Gy kismedencei irradiáció, valamint $2 \times 7$ Gy intracavitalis kezelés történt. A kontroll képalkotó vizsgálat 5 esetben $20 \%$ alatti választ $(18,52 \%)-S D, 3$ esetben teljes regressziót igazolt $(11,11 \%)-\mathrm{CR}, 19$ esetben $(70,37 \%)$ $30 \%$-ot meghaladó parciális regressziót - PR.

A követési idő átlag 22,7 hónap (8-46) volt. 


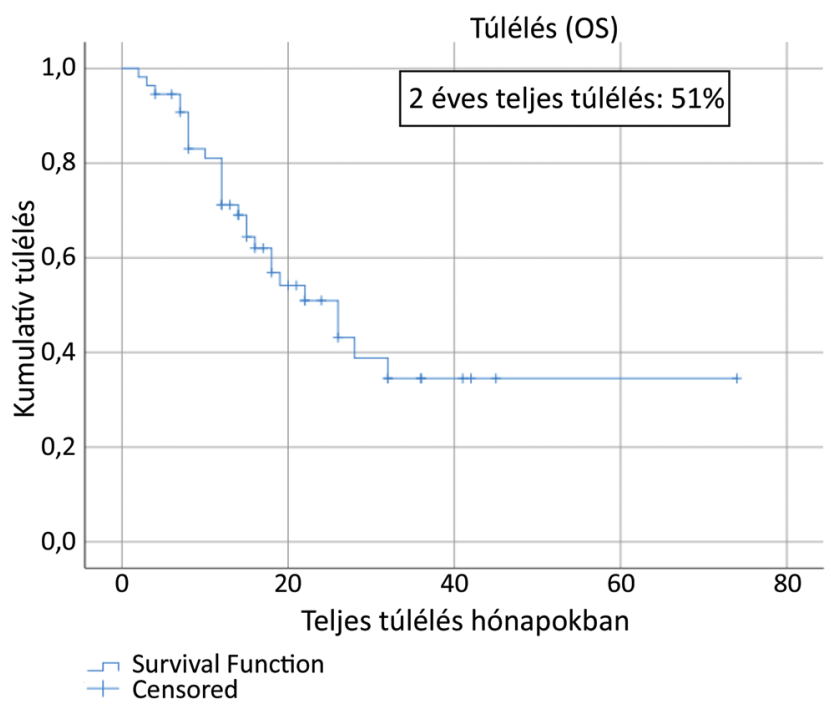

1. ábra

Az endometriumtumorral kezelt betegek teljes túlélésének ábrázolása differenciáló tényező hiányában

OS = teljes túlélés

Megvizsgáltuk az endometriumtumorral kezelt betegek teljes túlélését, melyet az 1 . ábra mutat. Az ábrázolt adatok alapján a 2 éves teljes túlélés $51 \%$, a medián túlélés pedig 15 hónap.

A neoadjuváns kezelésen, majd mútéten átesett betegcsoport hónapokban mért túlélési eredményeit a sugárkezelt betegcsoport túlélési eredményeivel hasonlítottuk össze, amit Kaplan-Meier-görbén ábrázoltunk (2. ábra). A statisztikai analízis során hosszabb túlélést észleltünk a neoadjuvánsan előkezelt betegcsoportnál. Az átlagos be-

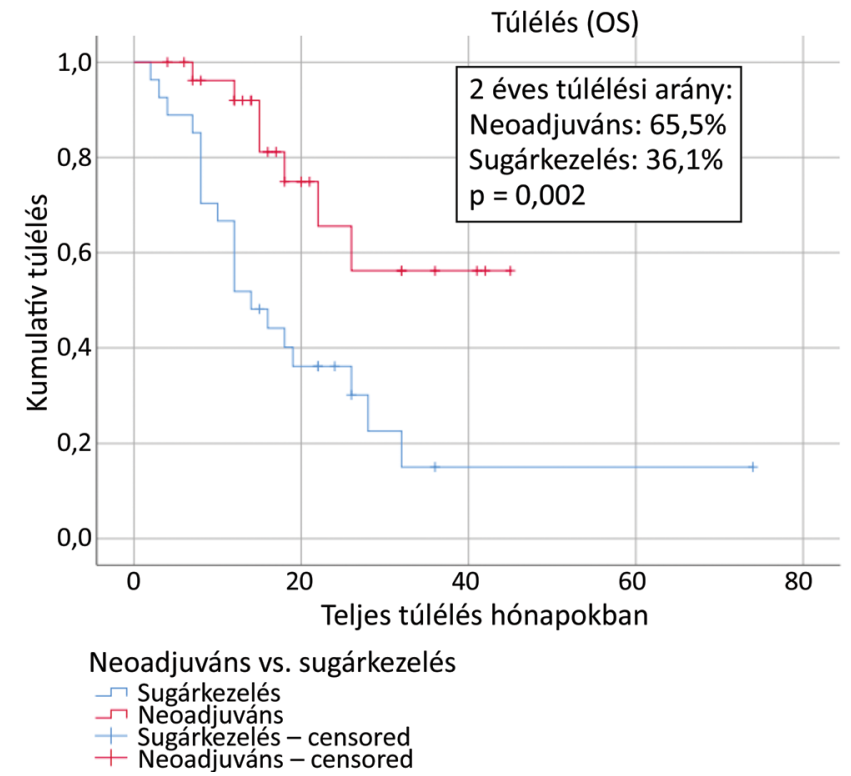

2. ábra

A neoadjuváns kezelésen, majd mútéten átesett betegcsoport túlélési eredményeinek összehasonlítása a sugárkezelt betegcsoport túlélési eredményeivel

OS = teljes túlélés

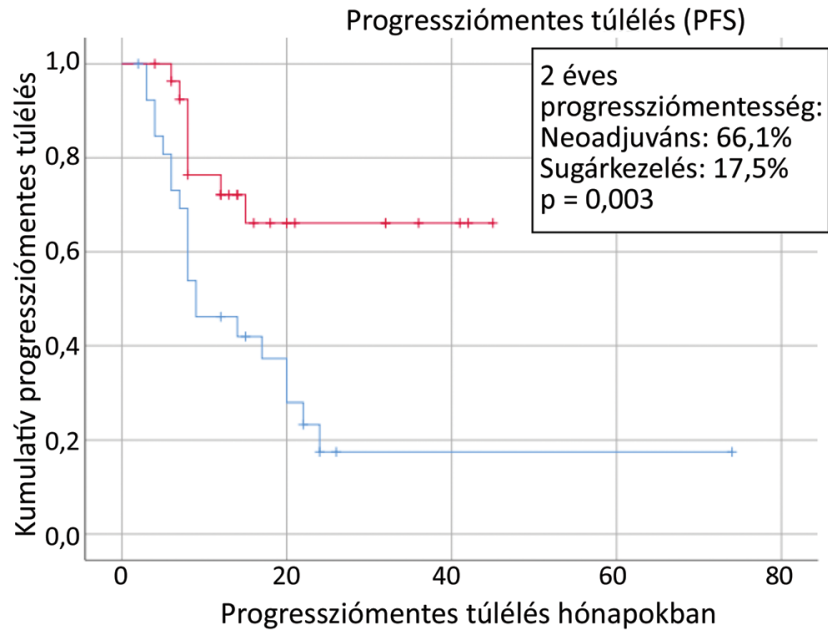

Neoadjuváns vs. sugárkezelés

$\neg$ Sugárkezelés

- Sugárkezelés - censored

- Neoadjuváns - censored

3. ábra

A neoadjuváns kezelésen, majd mútéten átesett betegcsoport progressziómentes túlélési eredményeinek összehasonlítása a sugárkezelt betegcsoport progressziómentes túlélési eredményeivel

csült túlélés a neoadjuváns kezelésen, majd mútéten átesett csoportban 33,294 hó; a csak sugárkezelésben részesített csoportban 23,784 hó. A 2 éves túlélési arány az elókezelt, majd megmútött betegcsoportnál 65,5\%-nak bizonyult, a sugárkezelt betegcsoportnál 36,1\%-ot észleltünk. A log-rank (Mantel-Cox-) teszt alapján az eredmények szignifikánsnak bizonyultak $\left(\mathrm{p}=0,002, \chi^{2}\right.$ : $9,230)$.

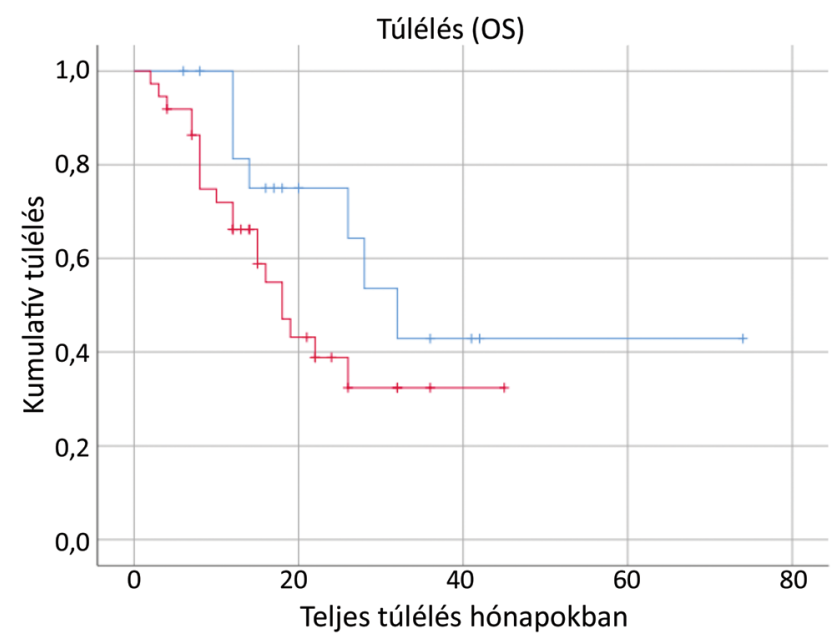

Hypertonia

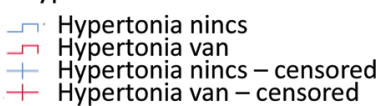

4. ábra $\quad$ A magas vérnyomás hatása az endometriumtumoros páciensek teljes túlélésére

OS = teljes túlélés 


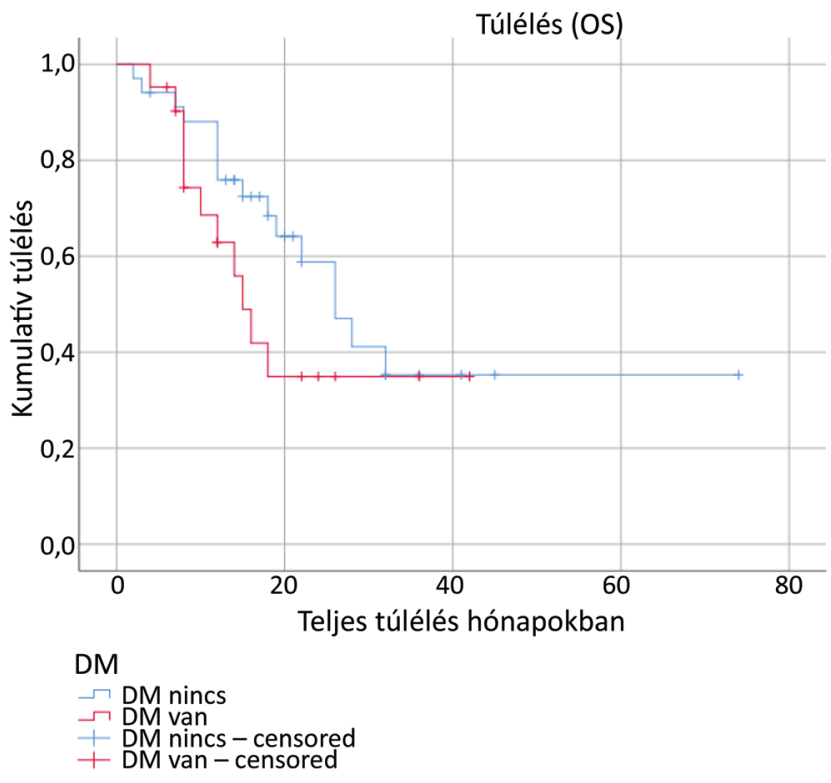

5. ábra

A diabetes hatása az endometriumtumoros páciensek teljes túlélésére Kaplan-Meier-görbén ábrázolva

$\mathrm{DM}=$ diabetes mellitus; $\mathrm{OS}=$ teljes túlélés

A neoadjuvánsan kezelt betegek 56\%-os valószínúséggel élik meg a 45 hónapot, ugyanez a sugárkezelteknél csupán $15 \%$.

A hónapokban mért progressziómentes túlélést is megvizsgáltuk mindkét betegcsoport esetén. A 2 éves progressziómentesség 17,5\% volt a nem operált betegeknél, ugyanez a neoadjuváns kezelésben részesített, majd megmútött betegcsoportnál 66,1\%-nak bizonyult (3. ábra). A medián progressziómentesség az irradiált betegcsoportnál 9 hónap volt, a neoadjuváns kezelésben részesített, majd megmútött betegcsoportban 18 hónap. A különbség szignifikánsnak tekinthető $\left(\mathrm{p}=0,003, \chi^{2}\right.$ : 8,698 ).

A progrediáló esetek közül l esetben távoli metastasis (tüdő) volt diagnosztizálható (a mútét utáni adjuváns kemoterápiát nem fogadta el), 3 esetben lokoregionális progresszió volt.

A prediktív tényezők túlélést befolyásoló szerepét Kaplan-Meier-féle túlélés-analízissel mértük fel, valamint Cox-regressziót alkalmaztunk. Megvizsgáltuk a két betegcsoportban a daganat felismerésekor levett CAl25 tumormarker szintjének befolyásoló szerepét. Az elhalálozott betegek átlagos tumormarkerértéke magasabbnak bizonyult (átlag 67,778), mint az életben lévőké (átlag $43,354)$, szignifikáns különbség azonban nem igazolódott a két csoport CAl25-értékében $(\mathrm{p}=0,150)$. Az életkor differenciáló szerepét kétmintás t-próbával vizsgáltuk. Az elhalálozott betegek átlagéletkor-értéke magasabb: átlag 69,7 év, SD: 8,179. Az élő betegek átlagéletkor-értéke: 60,8 év, SD: 8,179. A különbség szignifikánsnak bizonyult: $\mathrm{p}<0,001, t=3,828$. A magas vérnyomás befolyásoló szerepét vizsgálva nem találtunk szignifikáns különbséget ( $\left.\mathrm{p}=0,106, \chi^{2}: 2,619\right)$, az ábrázolt adatok alapján azonban látszik, hogy a hypertoniás betegek esélyei kissé rosszabbak, amit a 4. ábra mutat.

A diabetes túlélésre gyakorolt kóroki hatását vizsgálva azt tapasztaltuk, hogy a magas vérnyomáshoz hasonlóan nem tekinthető differenciáló tényezőnek, azaz a diabeteses betegek túlélési esélyei nem rosszabbak a diabetes diagnózisával nem rendelkező betegek túlélési esélyeinél $\left(\mathrm{p}=0,215, \chi^{2}: 1,540\right)$, amit az 5. ábra mutat.

\section{Megbeszélés}

Az irreszekábilis, lokálisan előrehaladott endometriumtumor esetén teljes kismedencei irradiáció és intracavitalis brachytherapia kombinálása, valamint szelektált betegek esetén szisztémás kemoterápia alkalmazása javasolt a nemzetközi ajánlásokban. Szisztémás kemoterápia alkalmazása mútét előtt a tumortömeg csökkentése céljából lehetővé teheti a megelőzően irreszekábilis folyamat operálhatóságát, felismerhetővé teszi a kemoszenzitív betegcsoportot, valamint kevésbé agresszív mútéti technika alkalmazásához vezethet, csökkentve így a morbiditást. A neoadjuváns szisztémás kezelés alkalmazása kedvezőbb túlélési eredményekkel és maximális tumordebulkinggal járhat, a posztoperatív szövődmények alacsonyabb rizikója mellett. A lokálisan, illetve lokoregionálisan előrehaladott, magas kockázatú endometriumdaganat heterogén betegség, gyakran ad mikroszkópos és makroszkópos peritonealis, valamint pulmonalis metastasisokat, a petefészek-daganatokhoz hasonlóan. A Cancer Genome Atlas Research Network endometriumtumorok genomikus, transzkripciós és proteomikus karakterisztikáját vizsgálva azt igazolta, hogy serosus papillaris méhtestdaganatok és magas gradusú serosus petefészek-daganatok azonos szomatikus mutációs és génexpressziós mintázatot mutatnak. A TP53-mutáció magas gyakorisággal, a PTEN-mutáció alacsony gyakorisággal fordul elő mindkét szubtípus esetén, valamint mindkettőben alacsony az ösztrogén/progeszteron receptor szintje [3].

Retrospektív vizsgálatok és metaanalízisek a progreszsziómentes és teljes túlélés tekintetében szignifikáns előnyt mútéttel elért optimális cytoreductio esetén találtak $[13,14]$. Az első közleményt neoadjuvás szisztémás kezeléssel kapcsolatban 1996-ban publikálták Resnik és $m$ tsai [15], melyet számos közlemény követett [16-21]. Kulcsfontosságúnak tartják a 2009-ben megjelent, Vandenputáltal közölt prospektív vizsgálatot, amelyben neoadjuváns platinabázisú kezelést követően a betegek $74 \%$ ában észleltek komplett és parciális választ, valamint az elvégzett mútétek 92\%-ában maximális cytoreductiót értek el. Magasabb átlagos teljes túlélést (23 hónap), progressziómentes túlélést (13 hónap) észleltek a primeren operált betegekhez képest, kevesebb posztoperatív szövődmény mellett (13\%). Vizsgálatunkban komplett és parciális válasz a betegek $89,27 \%$-ában volt, minden esetben sikerült a teljes tumoreltávolítás. Az átlagos tel- 
jes túlélés 33 hónapnak bizonyult, valamint a progreszsziómentes túlélés szintén magasabb (18 hónap) volt, mint azt a sugárterápiával kezelt betegcsoportnál tapasztaltuk. A residualis tumorméret mutatott szignifikáns összefüggést a teljes túléléssel, melyet prognosztikai tényezőnek tekintenek [22]. Az ESMO-ESGO-ESTRO Konszenzuskonferencia 2016. évi összefoglaló közleménye is csak teljes makroszkópos cytoreductio elvégezhetősége esetén javasolja a mütét elvégzését, mely vizsgálatunkban kivitelezhető volt minden operált páciens esetén. Egy másik munkacsoport hangsúlyozza, hogy a szisztémás előkezelés segítséget nyújthat a kemoszenzitív tumorral rendelkező betegek megválasztásában, akik profitálnak az intervallummütét elvégzéséből. Továbbá a csökkent tumorméret kedvezőbb reszekciós feltételeket és kevésbé agresszív mütétet tesz lehetővé, csökkentve a mütét elvégzésének idejét, a posztoperatív szövődményeket és kórházi ápolás időszakát, valamint növelve a beteg életminőségét [23]. A szisztémás kezelés jól tolerálható, a maximális debulking aránya magas, amit a jelen vizsgálatban is megtapasztaltunk.

Több nagy retrospektív vizsgálat is megerősítette az optimális cytoreductio szignifikáns előnyét III-IV. stádiumú EC esetén [24-26]. Egy 426 beteg anyagát retrospektíven feldolgozó japán vizsgálat IV/B stádiumú EC esetén 3 karú vizsgálatot végzett: operáció vagy neoadjuváns kemoterápiát követő mútét vagy palliatív ellátás. Szignifikáns túlélésbeli előnyt találtak a mütéti és neoadjuvánsan kezelt karon, szemben a palliatív ellátással [27]. De Lange és mtsai endometrioid és serosus szubtípusú carcinomák esetén vizsgálták a neoadjuváns kemoterápia alkalmazását; eredményeik szerint a rekurrenciaráta $56 \%$, illetve 67\%, a progressziómentes túlélés 18, illetőleg 13 hónap, az átlagos teljes túlélés 24 , illetve 28 hónap volt [28]. Bogani munkacsoportja IV/B stádiumú serosus endometriumtumorok esetén vizsgálták a neoadjuváns kemoterápia és intervallummútét alkalmazását, összehasonlítva az elsődlegesen operált és adjuváns kezelést kapó betegcsoporttal. A medián betegségmentes túlélés 12, illetőleg 15 hónap, a medián teljes túlélés 16, illetőleg 18 hónap volt, viszont az előkezelt csoportnál lényegesen rövidebb volt az operáció ideje, a kórházi tartózkodás és a szupportációs igény [29].

A szisztémásan előkezelt betegcsoport meglehetősen heterogén. Khouri és mtsai különböző szubtípusú, IIIIV. stádiumú daganatokat kezeltek: serosus, endometrioid, carcinosarcoma-, világos sejtes, kevert és neuroendokrin tumorokat. A kemoterápia tekintetében nagyrészt paklitaxel-karboplatint alkalmaztak; néhány beteg egyedüli paklitaxel- és egyedüli karboplatinkezelést kapott, ami szintén hatékonynak bizonyult. Eredményeik szerint annál a betegcsoportnál, amelynél az előkezelés után kivitelezhetô volt a mütét, a teljes túlélés 10 hónapos előnnyel járt. A megmútött páciensek esetén ez 16 hónap volt, az inoperábilis betegek esetében pedig 6 hónap [30]. A neoadjuváns kezelést mint választási lehetőséget lokálisan és lokoregionálisan előrehaladott endometri- umtumorok esetén a 2018-as FIGO Cancer Report is megemlíti [31]. Nőgyógyászati daganatokban környező szervi érintettség (hólyag, végbél) esetén fokozott a fistulaképződés veszélye, mert az itt létrejövő gyulladásos elváltozás a széklet és a vizelet folyamatos irritáló hatása miatt regenerációra képtelen, végül szöveti elhaláshoz vezet. A szisztémás kezeléssel elérhető tumorméretcsökkenés, valamint mútéti eltávolítás következtében a fistulaképződés kockázata csökkenhet, ami életminőségbeli előnnyel járhat.

\section{Következtetés}

Az utóbbi évtizedben kevés új hatékony terápiás irányelv született az EC-k túlélésének javítására. A sugárterápiában létrejött technikai fejlődés sem vezetett új protokollok létrejöttéhez. A mútéttel elért cytoreductio különböző daganatos megbetegedések esetén is növelheti az életkilátásokat, különösen teljes reszekció elérése esetén. A szakirodalmat és a nemzetközi ajánlásokat figyelembe véve vetődött fel vizsgálati célként a reszekabilitás esélyének növelése. Vizsgálati eredményeink alapján a mútét előtti szisztémás előkezelés hatékony eljárás lehet lokálisan és lokoregionálisan előrehaladott III/A-IV/A stádiumú, magas kockázatú endometriumtumoros betegeknél a daganat mútéti eltávolíthatóságának fokozása érdekében. Neoadjuváns kezelés alkalmazásával a teljes eltávolítás kivitelezhetô volt, a reszekciós szélek minden esetben épek voltak. A diabeteses betegek túlélési esélyei nem rosszabbak a diabetes diagnózisával nem rendelkező betegek túlélési esélyeinél. A hypertoniás betegek túlélési esélyei rosszabbak, de statisztikailag nem szignifikáns az eltérés. A CA125 tumormarkernek nincs prediktív jelentősége az életkilátások tekintetében. Amennyiben a kardiális status és az általános állapot engedi, a kezelés alkalmazásának életkori felső határa nincs, a magasabb életkor azonban statisztikailag kedvezőtlenebb kimenetellel jár. Az egyre fiatalabb életkorban diagnosztizált daganat miatt megfontolandó a terápiás lehetőség a reszekabilitás esélyeinek növelése érdekében. A szövettani szubtípusok közül a rossz prognosztikájú serosus papillaris és világos sejtes variáns esetén előnyös a neoadjuváns kezelés. A preoperatív alacsony gradus félrevezető lehet, hiszen nem feltétlenül mutat reális képet a teljes daganat hisztológiai sajátságairól, csak a teljes mútéti eltávolítás után értékelhető a valós patológiai viselkedés. A választott cytotoxicus kombináció jól tolerálható, hatékony terápiás effektussal. A kiindulási status felméréséhez, valamint a terápiás válasz monitorozásához elengedhetetlen a has-kismedence MR-vizsgálata. A 4 ciklus után elvégzett kontroll-MR-vizsgálat optimálisnak tûnik a kezelés komplettálása vagy a terápiaváltás megítélésére, vagyis a valóban kemoszenzitív betegcsoport szelektálására. Leginkább a környező szerv fali érintettségével diagnosztizált betegcsoport juthat előnyhöz a kezelésből, mivel itt a legmagasabb a fistulaképződés kockázata. A definitív dózisú sugárkezeléssel összeha- 
sonlítva lehetőség nyílik a tumor mütéti eltávolítására, mivel a kismedencére leadott összdózis után a fellépő késői mellékhatások miatt a mútét általánosságban nehezen kivitelezhetô, valamint fokozottabb a posztoperatív morbiditás. A sugárkezelés alkalmazása prolongálható. A cytoreductio következtében elvégezhetô mútét jobb túléléshez vezethet a szakirodalmi adatoknak megfelelően. A posztoperatív T-stádium eredményei azt mutatják, hogy sokkal alacsonyabb az elörehaladottabb stádiumú daganatok aránya, szemben a mútét előtti $\mathrm{T}$-stádium eredményeivel. A posztoperatív terápia meghatározásakor a jó regressziót követően a patológiai staging során kapott stádium értékelésekor a kiindulási statust is figyelembe kell venni, csakúgy, mint az onkológia egyéb területein meghatározó a neoadjuváns kezelést követő mütét után az adjuváns terápia meghatározásakor. Nagy valószínúséggel multimodális kezeléstôl várhatók a legjobb eredmények. A vizsgált betegcsoport kis elemszámú, a kezdeti eredmények azonban biztatóak. További tapasztalatszerzésre nagyobb betegszám és hosszabb követési idő szükséges.

Anyagi támogatás: A közlemény megírása anyagi támogatásban nem részesült.

Szerzői munkamegosztás: K. J. és G. P. az ötletadók és adatgyújtők. P. Sz., Bohonyi N. és Bárdos N. a beteganyag gyújtésében vett részt. Cs. M. a statisztikai részben segített, K. M. és T. G. L. a véleményezésben, K. K. a pathológiai rész revíziójában vett részt. A kézirat összeállítója K. K. A cikk végleges változatát valamennyi szerző elolvasta és jóváhagyta.

Érdekeltségek: A szerzőknek nincsenek érdekeltségeik.

\section{Irodalom}

[1] Bodoky Gy. Cancer of the endometrium. Epidemiology, risk factors, screening. In: Bodoky Gy, Kopper L. (eds.) Breast and gynecological oncology. [Endometrium daganatai. In: Bodoky Gy, Kopper L. (szerk.) Emló- és nőgyógyászati onkológia.] Medicina Könyvkiadó, Budapest, 2012; pp. 216-218. [Hungarian]

[2] Paulin F, Somogyi A. Endometrium carcinoma. In: Kásler M. (ed.) Basics of oncology. [Endometrium carcinoma. In: Kásler M. (szerk.) Az onkológia alapjai.] Medicina Könyvkiadó, Budapest, 2017; pp. 692-709. [Hungarian]

[3] Cancer Genome Atlas Research Network, Kandoth C, Schultz $\mathrm{N}$, Cherniack $\mathrm{AD}$, et al. Integrated genomic characterization of endometrial carcinoma. Nature 2013; 497(7447): 67-73. [Published correction appears in Nature 2013; 500(7461): 242.]

[4] Ott PA, Bang YJ, Berton-Rigaud D, et al. Safety and antitumor activity of pembrolizumab in advanced programmed death ligand 1-positive endometrial cancer: results from the KEYNOTE-028 Study. J Clin Oncol. 2017; 35: 2535-2541.

[5] Fracasso PM, Blessing JA, Molpus KL, et al. Phase II study of oxaliplatin as second-line chemotherapy in endometrial carcinoma: a Gynecologic Oncology Group study. Gynecol Oncol. 2006; 103: 523-526.

[6] Gupta D, Owers RL, Kim M, et al. A phase II study of weekly topotecan and docetaxel in heavily treated patients with recur- rent uterine and ovarian cancers. Gynecol Oncol. 2009; 113: $327-330$.

[7] Miller DS, Blessing JA, Lentz SS, et al. A phase II trial of topotecan in patients with advanced, persistent, or recurrent endometrial carcinoma: a Gynecologic Oncology Group study. Gynecol Oncol. 2002; 87: 247-251.

[8] Muggia FM, Blessing JA, Sorosky J, et al. Phase II trial of the pegylated liposomal doxorubicin in previously treated metastatic endometrial cancer: a Gynecologic Oncology Group study. J Clin Oncol. 2002; 20: 2360-2364.

[9] Rose PG, Blessing JA, Lewandowski GS, et al. A phase II trial of prolonged oral etoposide (VP-16) as second-line therapy for advanced and recurrent endometrial carcinoma: a Gynecologic Oncology Group study. Gynecol Oncol. 1996; 63: 101-104.

[10] Miller DS, Blessing JA, Drake RD, et al. A phase II evaluation of pemetrexed (Alimta, LY231514, IND \#40061) in the treatment of recurrent or persistent endometrial carcinoma: a phase II study of the Gynecologic Oncology. Gynecol Oncol. 2009; 115 : 443-446.

[11] Tait DL, Blessing JA, Hoffman JS, et al. A phase II study of gemcitabine (gemzar, LY188011) in the treatment of recurrent or persistent endometrial carcinoma: a Gynecologic Oncology Group study. Gynecol Oncol. 2011; 121: 118-121.

[12] McMeekin DS, Lisyanskaya A, Crispens M, et al. Single-agent trabectedin as second-line therapy of persistent or recurrent endometrial cancer: results of a multicenter phase II study. Gynecol Oncol. 2009; 114: 288-292.

[13] Barlin JN, Puri I, Bristow RE. Cytoreductive surgery for advanced or recurrent endometrial cancer: a meta-analysis. Gynecol Oncol. 2010; 118: 14-18.

[14] Shih KK, Yun E, Gardner GJ, et al. Surgical cytoreduction in stage IV endometrioid endometrial carcinoma. Gynecol Oncol. 2011; 122: 608-611.

[15] Resnik E, Taxy JB. Neoadjuvant chemotherapy in uterine papillary serous carcinoma. Gynecol Oncol. 1996; 62: 123-127.

[16] Le TD, Yamada SD, Rutgers JL, et al. Complete response of a stage IV uterine papillary serous carcinoma to neoadjuvant chemotherapy with taxol and carboplatin. Gynecol Oncol. 1999; 73: 461-463.

[17] Price FV, Amin RM, Sumkin J. Complete clinical responses to neoadjuvant chemotherapy for uterine serous carcinoma. Gynecol Oncol. 1999; 73: 140-144.

[18] Despierre E, Moerman P, Vergote I, et al. Is there a role for neoadjuvant chemotherapy in the treatment of stage IV serous endometrial carcinoma? Int J Gynecol Cancer 2006; 16(Suppl 1): 273-277.

[19] Amant F, Vergote I. What is the role of neoadjuvant chemotherapy in advanced endometrial cancer? Gynecol Oncol. 2010; 119: 601 .

[20] Barlin JN, Bristow RE. Response to: "What is the role of neoadjuvant chemotherapy in advanced endometrial cancer?". Gynecol Oncol. 2010; 119: 601-602.

[21] Wilkinson-Ryan I, Frolova AI, Liu J, et al. Neoadjuvant chemotherapy versus primary cytoreductive surgery for stage IV uterine serous carcinoma. Int J Gynecol Cancer 2015; 25: 63-68.

[22] Vandenput I, Van Calster B, Capoen A, et al. Neoadjuvant chemotherapy followed by interval debulking surgery in patients with serous endometrial cancer with transperitoneal spread (stage IV): a new preferred treatment? Br J Cancer 2009; 101: 244-249.

[23] Rabinovich A. Neo-adjuvant chemotherapy for advanced stage endometrial carcinoma: a glimmer of hope in select patients. Arch Gynecol Obstet. 2016; 293: 47-53.

[24] Bristow RE, Zerbe MJ, Rosenshein NB, et al. Stage IVB endometrial carcinoma: the role of cytoreductive surgery and determinants of survival. Gynecol Oncol. 2000; 78: 85-91

[25] Lambrou NC, Gómez-Marín O, Mirhashemi R, et al. Optimal surgical cytoreduction in patients with Stage III and Stage IV endometrial carcinoma: a study of morbidity and survival. Gynecol Oncol. 2004; 93: 653-658. 
[26] Chi DS, Welshinger M, Venkatraman ES, et al. The role of surgical cytoreduction in Stage IV endometrial carcinoma. Gynecol Oncol. 1997; 67: 56-60

[27] Eto T, Saito T, Shimokawa M, et al. Status of treatment for the overall population of patients with stage IVb endometrial cancer, and evaluation of the role of preoperative chemotherapy: a retrospective multi-institutional study of 426 patients in Japan. Gynecol Oncol. 2013; 131: 574-580.

[28] de Lange NM, Ezendam NP, Kwon JS, et al. Neoadjuvant chemotherapy followed by surgery for advanced-stage endometrial cancer. Curr Oncol. 2019; 26: e226-e232.

[29] Bogani G, Ditto A, Leone Roberti Maggiore U, et al. Neoadjuvant chemotherapy followed by interval debulking surgery for unresectable stage IVB serous endometrial cancer. Tumori J. 2019; 105: 92-97.

[30] Khouri OR, Frey MK, Musa F, et al. Neoadjuvant chemotherapy in patients with advanced endometrial cancer. Cancer Chemother Pharmacol. 2019; 84: 281-285.

[31] Amant F, Mirza MR, Koska M, et al. Cancer of the corpus uteri. Int J Gynaecol Obstet. 2018; 143(Suppl 2): 37-50.

(Kalincsák Judit dr., Pécs, Édesanyák útja 17., 7628 e-mail: judit.kalincsak@gmail.com)

A Semmelweis Egyetem Általános Orvostudományi Kara örömmel tesz eleget annak a hagyománynak, hogy volt diákjait jubileumi díszoklevéllel tünteti ki.

Kérjük ezért azokat az orvosokat, akik diplomájukat az egyetem jogelődjénél, a BUDAPESTI KIRÁLYI MAGYAR PÁZMÁNY PÉTER TUDOMÁNYEGYETEMEN, a PÁZMÁNY PÉTER TUDOMÁNYEGYETEMEN, a BUDAPESTI ORVOSTUDOMÁNYI EGYETEMEN, IlletVe a SEMMELWEIS ORVOSTUDOMÁNYI EGYETEMEN

$$
\begin{aligned}
& 1945 \text {-ben } \\
& 1950 \text {-ben } \\
& 1955 \text {-ben } \\
& 1960 \text {-ben } \\
& 1970 \text {-ben }
\end{aligned}
$$

szerezték meg, és szakterületükön legalább 30 évig dolgoztak, nyújtsák be kérelmüket a platina, rubin, vas, gyémánt, illetve arany díszoklevél elnyerése érdekében 2020. április 30-ig, a következő címre, az alábbi jelentkezési lapon.

\section{Semmelweis Egyetem Általános - Orvostudományi Kar \\ Dékáni Hivatal \\ 1085 Budapest, Üllői út 26. vagy 1428 Budapest Pf. 2}

A jubileumi díszoklevelek átadására előreláthatóan októberben kerül sor. A pontos időpontról meghívó útján küldünk értesítést.

\section{JELENTKEZÉSI LAP \\ arany, gyémánt, vas, rubin és platina díszoklevélhez}

NÉV

(névváltoztatás feltüntetésével)

Születési idő:

Diploma kelte:

Lakcím:

Telefonszám:

E-mail cím:

Utolsó munkahely:

Rövid szakmai önéletrajz:

Aláírásommal hozzájárulok ahhoz, hogy fenti adataimat - az ALUMNI tevékenységgel összefüggésben - a SEMMELWEIS ALUMNI Iroda kezelje.

Dátum:

kérelmező aláirása

Aláírásommal hozzájárulok ahhoz, hogy a lakóhelyem szerinti illetékes önkormányzat megkeresésére, kerületi ünnepségre történő meghívás céljából az elérhetőségeim kiadásra kerüljenek.

A megfelelő válasz aláhúzandó. $\quad$ IGEN NEM

A cikk a Creative Commons Attribution 4.0 International License (https://creativecommons.org/licenses/by/4.0/) feltételei szerint publikált Open Access közlemény, melynek szellemében a cikk bármilyen médiumban szabadon felhasználható, megosztható és újraközölhető, feltéve, hogy az eredeti szerző és a közlés helye, illetve a CC License linkje és az esetlegesen végrehajtott módosítások feltüntetésre kerülnek. (SID_1) 